MEDIA PERKECAMBAHAN BENIH TUMBUHAN KAYU GULA (Aphanamixis polystachya (Wall.) R.N. Parker) Diana Prameswari, Rosita Dewi, dan Rima HS Siburian

\title{
MEDIA PERKECAMBAHAN BENIH TUMBUHAN KAYU GULA (Aphanamixis polystachya (Wall.) R.N. Parker)
}

\author{
(Germination Media of Sugar Wood (Aphanamixis polystachya (Wall) R.N. Parker)
}

Diana Prameswari ${ }^{1}$, Rosita Dewi ${ }^{1}$, dan/and Rima HS Siburian ${ }^{2}$

${ }^{1)}$ Pusat Standardisasi Instrumen Pengelolaan Hutan Berkelanjutan,

Jl. Gunung Batu No 5. Telp 0251- 8633234, Bogor, Indonesia

${ }^{2}$ Fakultas Kehutanan Universitas Papua, Jl. Gunung Salju Amban Manokwari-Papua Barat, Indonesia e-mail:diana_eko@yahoo.com

Naskah masuk: 11 November 2021; Naskah direvisi: 23 November 2021; Naskah diterima: 15 Desember 2021

\begin{abstract}
Sugar wood (Aphanamixis polystachya (Wall) R.N. Parker) is a medicinal plant that is widely used for herbal medicine. Sugar wood distribution areas are China, India, Sri Lanka, Thailand, Laos, Vietnam, Malaysia, Indonesia, Philippines, New Guinea, and the Solomon Islands. However, nowadays sugar wood trees are increasingly difficult to find, so they need to be cultivated by planting. The purpose of this study was to determine the best type of media for the germination of sugar wood seeds (A. polystachya). The research was conducted in the nursery of Forest Research and Development Centre Bogor. The method used in this study is an experimental method using a single factor completely randomized design technique with three replications. The media factor consisted of soil, sand, soil mixed with rice husk (2:1), and soil mixed with charcoal (2:1). Parameters observed were: germination, speed of germination, seed moisture content, and germination value. The results showed that the use of sand media had the highest germination speed and germination value (14.00\% per etmal and $13.80 \%)$ while the use of soil media had the lowest germination speed and germination value $(32.33 \%$ per etmal and $7.52 \%)$. Otherwise germination capacity of seed ranging from $64.67 \%$ (on soil media) - $91.33 \%$ (on mixed media of soil and rice husk).
\end{abstract}

Keywords: Aphanamixis polystachya, germination, media, seed

\begin{abstract}
ABSTRAK
Kayu gula (Aphanamixis polystachya (Wall) R.N. Parker) merupakan tumbuhan berkhasiat obat yang banyak digunakan untuk pengobatan herbal. Daerah penyebaran kayu gula adalah Tiongkok, India, Sri Lanka, Thailand, Laos, Vietnam, Malaysia, Indonesia, Philippines, New Guinea dan Kepulauan Solomon. Namun saat ini pohon kayu gula semakin sulit ditemukan sehingga perlu dibudidayakan dengan melakukan penanaman. Tujuan penelitian ini adalah untuk mengetahui jenis media yang terbaik dalam perkecambahan benih kayu gula (A. polystachya). Penelitian dilakukan di persemaian Pusat Penelitian dan Pengembangan Hutan Bogor. Metode yang digunakan dalam penelitian ini adalah metode eksperimental menggunakan rancangan acak lengkap faktor tunggal dengan tiga ulangan. Faktor media terdiri dari: tanah, pasir, tanah + sekam padi (2:1) dan tanah + arang (2:1). Parameter yang diamati adalah: daya tumbuh, kecepatan berkecambah, kadar air benih dan nilai kecambah. Hasil penelitian menunjukan bahwa penggunaan media pasir memiliki kecepatan perkecambahan dan nilai kecambah tertinggi $(14,00 \%$ per etmal dan $13,80 \%)$ sedangkan penggunaan media tanah memiliki kecepatan perkecambahan dan nilai kecambah terendah (32,33\% per etmal dan 7,52\%). Selain itu daya kecambah benih berkisar antara $64,67 \%$ (pada media tanah) $91,33 \%$ ( pada media campuran tanah dan sekam padi).
\end{abstract}

Kata kunci : Aphanamixis polystachya, benih, media, perkecambahan

\section{PENDAHULUAN}

Indonesia merupakan negara tropis yang memiliki kekayaan alam yang sangat besar bahkan dikenal dengan megabiodiversitasnya. Soerianegara (1998) mengungkapkan bahwa setiap jenis tumbuhan mempunyai kisaran toleransi tertentu terhadap lingkungannya. Batas kisaran toleransi ini dikenal ada dua sifat, yaitu batas toleransi sempit (steno) dan lebar (eury). Jenis-jenis tumbuhan dengan

*Kontribusi penulis Diana Prameswari, Rosita Dewi, dan Rima HS Siburian sebagai kontributor utama 
toleransi lebar (eury) dapat berhasil tumbuh dengan kondisi lingkungan yang seragam karena cenderung menyebar luas (Subarna, 2011).

Kayu gula (Aphanamixis polystachya) atau yang dikenal di India dengan nama pohon Pithraj (Mathew et al., 2017) merupakan salah satu tanaman pohon berbunga dari famili Meliaceae yang dapat dijumpai pada daerah tropis maupun sub tropis. Kayu gula merupakan tumbuhan berkhasiat obat tradisional yang telah banyak digunakan dalam pengobatan herbal. Pemanfaatan kayu gula adalah untuk mengobati penyakit tumor, kanker, reumatik, limpa, dan juga sebagai anti mikroba (Saklani et al., 2012). Bagian dari kayu gula yang dapat dimanfaatkan untuk pengobatan adalah: daun, kulit batang dan bijinya yang banyak mengandung minyak atsiri. Biji kayu gula juga menjadi sumber baru dalam pengembangan bioethanol (Mathew et al., 2017).

Penyebaran tumbuhan kayu gula adalah dari daerah barat hingga timur seperti : Tiongkok, India, Sri Lanka, Thailand, Laos, Vietnam, Malaysia, Indonesia, Philippines, New Guinea dan Kepulauan Solomon. Tumbuhan kayu gula di alam dapat tumbuh pada ketinggian 400 hingga 600 meter dari permukaan laut dan umumnya pada daerah sepanjang sungai-sungai (Anggraeni et al., 2013) .
Tumbuhan kayu gula saat ini banyak diburu oleh masyarakat untuk digunakan sebagai tanaman obat dan bahkan ada yang menggunakannya sebagai kayu bakar, sehingga keberadaan tanaman ini sudah mulai sulit dijumpai di alam. Eksploitasi kayu gula dari alam secara terus menerus dapat menurunkan populasinya dan mengancam kelestariannya. Berbagai upaya untuk menanggulangi penurunan populasi kayu gula dapat dilakukan salah satunya adalah melalui kegiatan penanaman baik di dalam habitat (in situ) maupun di luar habitatnya (ex situ).

Dalam menunjang keberhasilan kegiatan penanaman kayu gula, ketersediaan bibit yang cukup sangat diperlukan. Suryanto (2013) mengemukakan bahwa ketersediaan bibit merupakan faktor yang sangat perlu diperhatikan di dalam pembangunan hutan tanaman. Tumbuhan A. polystachya merupakan famili meliaceae dan benihnya memiliki karakteristik intermediate dengan kadar air sedang. Benih intermediet merupakan benih yang memiliki watak diantara benih ortodok dan rekalsitran. Benih intermediet dapat dikeringkan sampai kadar air 12\%-17\%. Benih intermediet sensitif terhadap pengeringan di bawah sinar matahari (Sudrajat, 2017). Penggunaan teknik yang tepat dalam penanganan benih intermediet perlu dilakukan untuk meningkatkan keberhasilan tumbuh yang tinggi. 
Perkecambahan merupakan fase awal perkembangan tumbuhan. Perkecambahan dari beberapa jenis tumbuhan juga memiliki batas toleransi dan sangat dipengaruhi oleh kondisi lingkungannya, seperti: ketersediaan air, oksigen dan suhu udara (Jumini, 2006). Media perkecambahan sebagai salah satu factor lingkungan yang mempengaruhi pertumbuhan benih tanaman. Media perkecambahan yang baik adalah media perkecambahan optimum yang mampu menyediakan semua unsur hara dan air yang dibutuhkan oleh tanaman (Taryana, 2019).

Tujuan penelitian ini adalah untuk mengetahui media tumbuh terbaik pada perkecambahan benih kayu gula. Hasil penelitian ini diharapkan dapat menjadi bagian dari ilmu pengetahuan dan teknologi di dalam perbanyakan bibit kayu gula.

\section{BAHAN DAN METODE}

\section{A. Alat dan Bahan}

Bahan yang digunakan pada kegiatan penelitian ini adalah: benih $A$. polystachya, tanah, arang, pasir dan sekam padi. Alat yang digunakan pada penelitian ini terdiri: saringan, bak kecambah, sprayer, alat tulis, alat ukur dan alat dokumentasi. Penelitian ini dilakukan di persemaian Pusat Penelitian dan Pengembangan Hutan - Bogor, pada bulan Mei - Juli 2017.

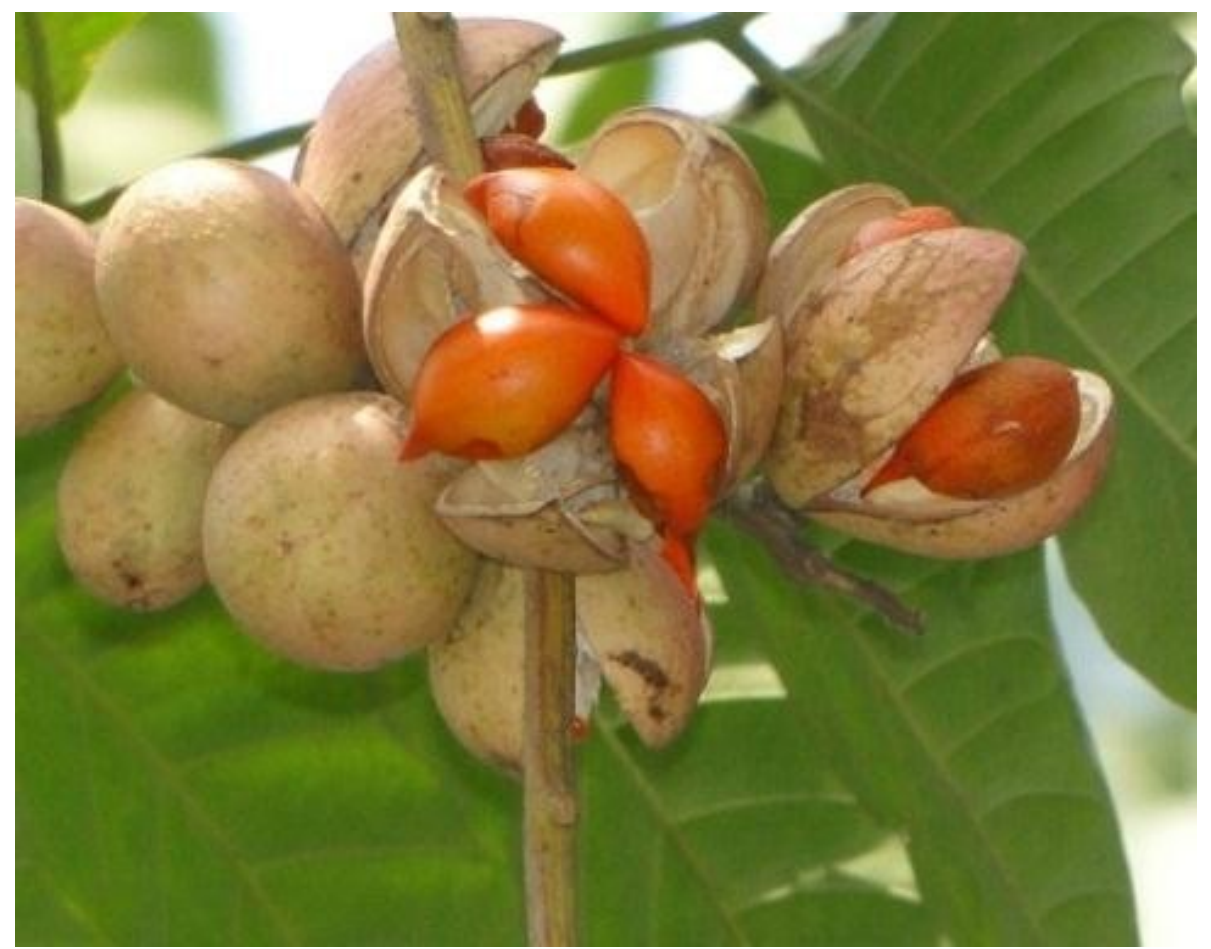

Sumber (source): (Rai, 2014)

Gambar (Figure) 1. Buah Aphanamixis polystachya yang sudah masak (The matured fruits of Aphanamixis polystachya). 


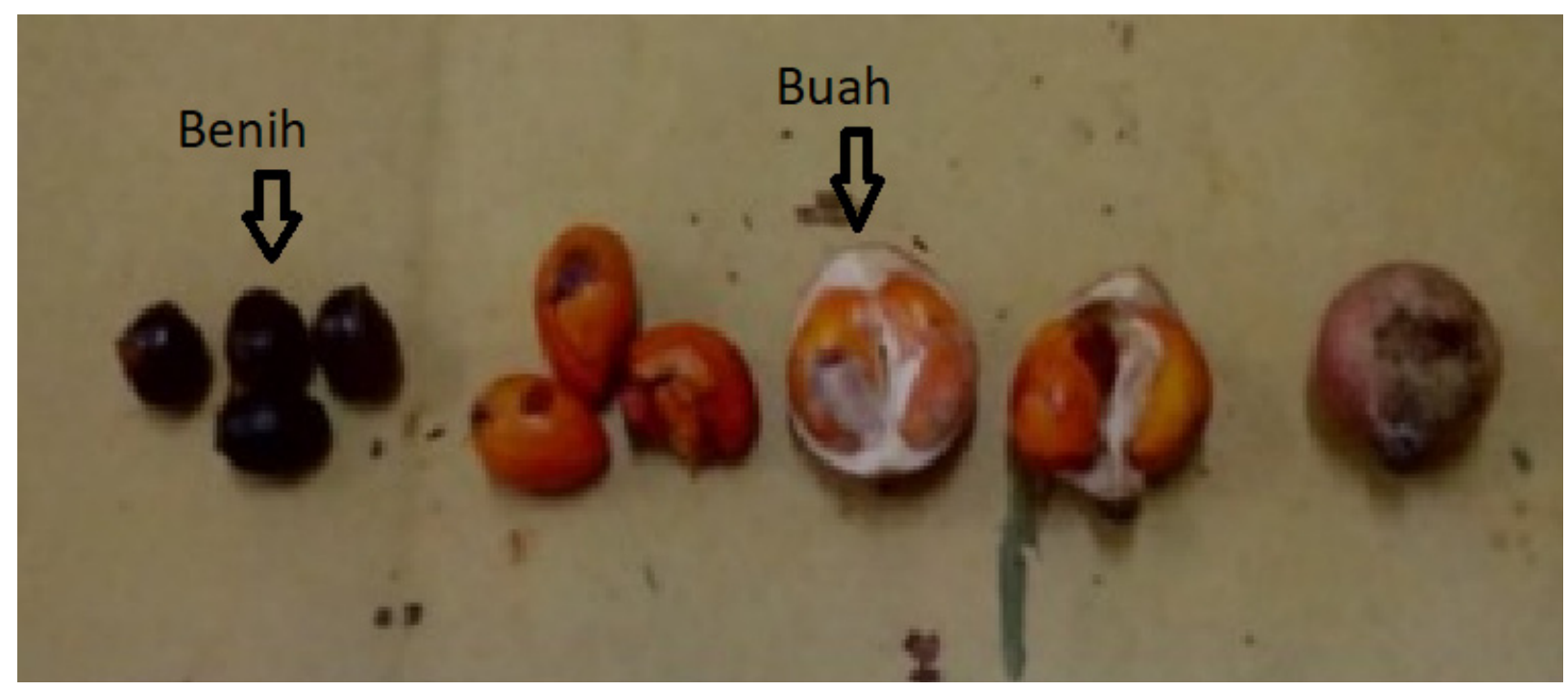

Gambar (Figure) 2. Buah dan benih Aphanamixis polystachya (Aphanamixis polystachya fruit and seeds)

\section{B. Prosedur Penelitian}

\section{Persiapan}

Benih A. polystachya merupakan hasil pengunduhan buah dari pohon koleksi ( $A$. Polystachya) pada ketinggian $\pm 270 \mathrm{~m} \mathrm{dpl}$ dengan koordinat 6035'49",106 46'51'yang berada di Arboretum Pusat Penelitian dan Pengembangan Hutan Bogor. Buah $A$. polystachya masak dengan kondisi berwarna kuning dan sudah pecah dipanen, kemudian benihnya dibersihkan dari daging buah dan kotoran lainnya. Benih A. Polystachya kemudian dikering anginkan selama 12 jam pada suhu kamar $28^{\circ} \mathrm{C}$ dengan kelembaban $80 \%$. Benih kayu gula termasuk pada jenis intermediet yang memiliki kadar air $>10 \%$. Benih intermediet dapat diturunkan kadar airnya mencapai $10 \%$, namun benihnya akan mengalami kerusakan jika kadar airnya diturunkan lagi. (Suita \& Syamsuwida, 2016)

\section{Perlakuan}

Sebelum dilakukan penyemaian, benih kayu gula diseleksi dahulu dengan cara merendamnya pada air dingin. Kegiatan perendaman ini dilakukan untuk mengetahui kualitas benih yang akan ditanam. Berdasarkan hasil seleksi tersebut, kemudian dipilih 600 benih kayu gula.

Penelitian ini dilaksanakan dengan menggunakan Rancangan Acak Lengkap (RAL) dengan faktor tunggal dan 3 (tiga) ulangan. Perlakuan pada penelitian ini adalah komposisi media tanam. Faktor media merupakan faktor tunggal yang terdiri dari:

1. $\mathrm{A} 1=$ Tanah + Sekam padi $(2: 1)$

2. $\mathrm{A} 2=\mathrm{Tanah}$

3. A3 $=$ Tanah + Arang $(2: 1)$

4. $\mathrm{A} 4=$ Pasir

Masing-masing media tanam kemudian disterilisasikan menggunakan autoklave 
dengan suhu $120^{\circ} \mathrm{C}$ tekanan 1,5 atm selama 30 menit. Kegiatan sterilisasi dilakukan terlebih dahulu untuk mencegah hama dan penyakit. Pasir dengan ukuran partikel 0,05 $\mathrm{mm}-2,0 \mathrm{~mm}$ disangrai terlebih dahulu, demikian juga dengan media tanah. Setelah semua media tanam siap, kemudian benih kayu gula (A. polystachya) yang telah diseleksi disemaikan pada masing-masing media tanam tersebut. Media tanam pada penelitian ini terdiri dari yaitu: tanah + sekam padi $(2: 1)$, tanah, tanah + arang (2:1), dan pasir. Masingmasing perlakuan diulang sebanyak 3 (tiga) kali. Jumlah benih per ulangan adalah 200 benih.

\section{Parameter Penelitian}

Parameter yang diamati dalam penelitian ini adalah: daya kecambah, kecepatan berkecambah, nilai kecambah dan kadar air. Hasil pengamatan kemudian dihitung menggunakan Sutopo (1988) dan Kamil (1982).

\section{a. Daya Tumbuh}

Daya Tumbuh ditentukan dengan menghitung jumlah benih yang tumbuh dari total benih yang disemaikan pada jangka waktu 30 hari.

$$
\text { Daya Tumbuh }=\frac{\Sigma \text { benih yang tumbuh }}{\Sigma \text { total benih yang disemaikan }} \times 100 \%(1)
$$

\section{b. Kecepatan Berkecambah}

Variabel yang dihitung dalam mengukur kecepatan berkecambah adalah benih yang berkecambah dari pengamatan hari pertama sampai dengan hari terakhir. Dengan penghitungan kecambah normal pada setiap pengamatan dibagi dengan etmal ( 1 etmal $=$ 24 jam). Rumus kecepatan berkecambah adalah sebagai berikut;

$\mathrm{Kct}=\sum_{i=1}^{n} \frac{(\mathrm{KN}) \mathrm{i}}{\mathrm{Wi}}$

Dimana :

Kct $\quad$ Kecepatan berkecambah

$\mathrm{i} \quad=$ Hari pengamatan

Kni = Kecambah normal pada hari ke i $(\%)$

$\mathrm{Wi}=$ Waktu etmal pada hari ke $\mathrm{i}$

\section{c. Kadar Air}

Kadar air dinyatakan dalam persen berat dan dihitung dalam 1 desimal terdekat. Rumus yang digunakan adalah:

Kadar air $(K A)=\frac{\text { Berat benih basah }- \text { Berat benih } \text { ker ing }}{\text { Berat benih basah }} \times 100 \%$

Pengujian kadar air benih menggunakan $5 \mathrm{~g}$ benih dengan 3 ulangan. Pengukuran kadar air dilakukan sebelum benih disemaikan. Penentuan kadar air benih kayu gula dilakukan dengan metode oven suhu tetap dilakukan pada suhu rendah $\left(101^{0} \mathrm{C}-105^{0} \mathrm{C}\right)$ selama 17 \pm 1 jam.

\section{d. Nilai Perkecambahan}

Satuan nilai perkecambahan yang dinilai adalah dalam persen kemampuan berkecambah harian sejak pengujian dimulai. Rumus yang digunakan adalah (Djavanshir \& Poerbeik, 1976).

$$
G V=\frac{D G S}{N} x(G P x 10)
$$

\section{Keterangan :}

DGS = Daily Germination Speed (laju perkecambahan harian), dihitung dengan membagi persentase 
perkecambahan kumulatif dengan jumlah hari sejak pengujian dimulai

GP = Germination percent (persentase perkecambahan), jumlah kecambahan normal yang ada sampai akhir perkecambahan

$\mathrm{N}=$ Frekuensi adalah angka yang dihitung sejak perhitungan DGS di mulai

$10=$ Konstanta yang digunakan dalam rumus ini

\section{Analisis Data}

Data hasil penelitian yang diperoleh kemudian dianalisis secara statistik menggunakan analisis sidik ragam (Uji F). Apabila terdapat pengaruh nyata antar perlakuan pada taraf kepercayaan 95\%, dilanjutkan dengan analisis DMRT (Duncan's
Multiple Range Test) pada taraf $5 \%$. Pengolahan data hasil penelitian menggunakan aplikasi Ms.Excel 2000 dan dianalisis menggunakan software SAS version 9.0.

\section{HASIL DAN PEMBAHASAN}

\section{A. Hasil}

Hasil pengamatan perkecambahan benih kayu gula (A. polystachya) pada penggunaan beberapa media tanam, yaitu: tanah + sekam padi, tanah, tanah + arang, dan pasir tersaji pada Tabel 1. Parameter-parameter yang diamati pada penelitian ini adalah daya kecambah, kecepatan berkecambah, kadar air, dan nilai kecambah.

Tabel (Table) 1. Hasil uji beda Duncan pengaruh media terhadap perkecambahan benih kayu gula (A. polystachya) ( (The results of Duncan test of the effect media on germination of $\underline{\mathrm{A}}$. polystachya seeds)

\begin{tabular}{lccc}
\hline \multirow{2}{*}{$\begin{array}{c}\text { Media } \\
\text { (Media) }\end{array}$} & \multicolumn{3}{c}{ Parameter (Traits) } \\
\cline { 2 - 4 } & $\begin{array}{c}\text { Daya tumbuh } \\
(\text { Germination })\end{array}$ & $\begin{array}{c}\text { Kecepatan tumbuh } \\
(\text { Germination speed }) \\
(\%)\end{array}$ & $\begin{array}{c}\text { Nilai Kecambah/ } \\
\text { Germination rate })\end{array}$ \\
\hline Tanah+Sekam Padi (soil + rice husk) & $91.33 \mathrm{a}$ & $24,67 \mathrm{~b}$ & $11,65 \mathrm{ab}$ \\
Tanah (soil) & $64.67 \mathrm{~b}$ & $32,33 \mathrm{a}$ & $7,52 \mathrm{c}$ \\
Tanah +Arang (soil + charcoal) & $88 \mathrm{a}$ & $18,33 \mathrm{c}$ & $10.32 \mathrm{bc}$ \\
Pasir (sand) & $96 \mathrm{a}$ & $14,00 \mathrm{~d}$ & $13,80 \mathrm{a} \mathrm{c}$ \\
\hline
\end{tabular}

Keterangan (Remarks): Nilai-nilai yang diikuti oleh huruf yang sama pada kolom yang sama tidak berbeda nyata pada selang kepercayaan 99\% berdasarkan Uji DMRT (Values followed by the same letters on the same column are not significantly different : $a>b>c<d$, etc. $P=99 \%)$. ** berbeda sangat nyata pada selang kepercayaan $99 \%$ (significant effect, $P=99 \%$ )

\section{Kadar air benih}

Untuk mengetahui karakter benih kayu gula maka dilakukan pengukuran kadar air benih. Berdasarkan hasil pengukuran kadar benih kayu gula yang dilakukan sebelum penyemaian, diperoleh hasil nilai kisaran kadar air benih kayu gula antara 11,22 \% hingga $13,89 \%$.

\section{Daya tumbuh}

Benih kayu gula (A. polystachya) pada penggunaan media pasir memiliki daya tumbuh $96 \%$ namun tidak berbeda nyata 
dengan penggunaan media tanah + sekam padi dan penggunaan media tanah + arang. Selanjutnya daya tumbuh benih kayu gula $(A$. polystachya) menggunakan media tanah + sekam padi adalah $91,33 \%$. Daya tumbuh benih kayu gula (A. polystachya) menggunakan media tanah + arang adalah $88 \%$. Daya tumbuh benih kayu gula $(A$. polystachya) terendah adalah pada penggunaan media tanah yaitu $64,67 \%$.

\section{Kecepatan berkecambah}

Bila dilihat pada parameter kecepatan berkecambah, benih kayu gula $(A$ polystachya) memiliki kecepatan berkecambah tercepat adalah pada penggunaan media pasir yaitu $14,00 \%$ per etmal. Kecepatan berkecambah benih kayu gula (A. polystachya) terlambat pada media tanah adalah $32,33 \%$ per etmal. Berdasarkan hasil analisis sidik ragam pada Tabel 1, berbagai perlakuan media berbeda nyata terhadap kecepatan berkecambah benih kayu gula (A. polystachya). Pemakaian berbagai jenis media juga menyebabkan saat berkecambah benih kayu gula (A. polystachya) berbeda-beda waktunya, berkisar 10-30 hari setelah tanam (Gambar 3). Penggunaan media pasir memiliki saat berkecambah benih kayu gula ( $A$. polystachya) tercepat yaitu 10 hari setelah tanam. Penggunaan media tanah memiliki saat berkecambah benih kayu gula (A. Polystachya) terlama yaitu 30 hari setelah tanam.

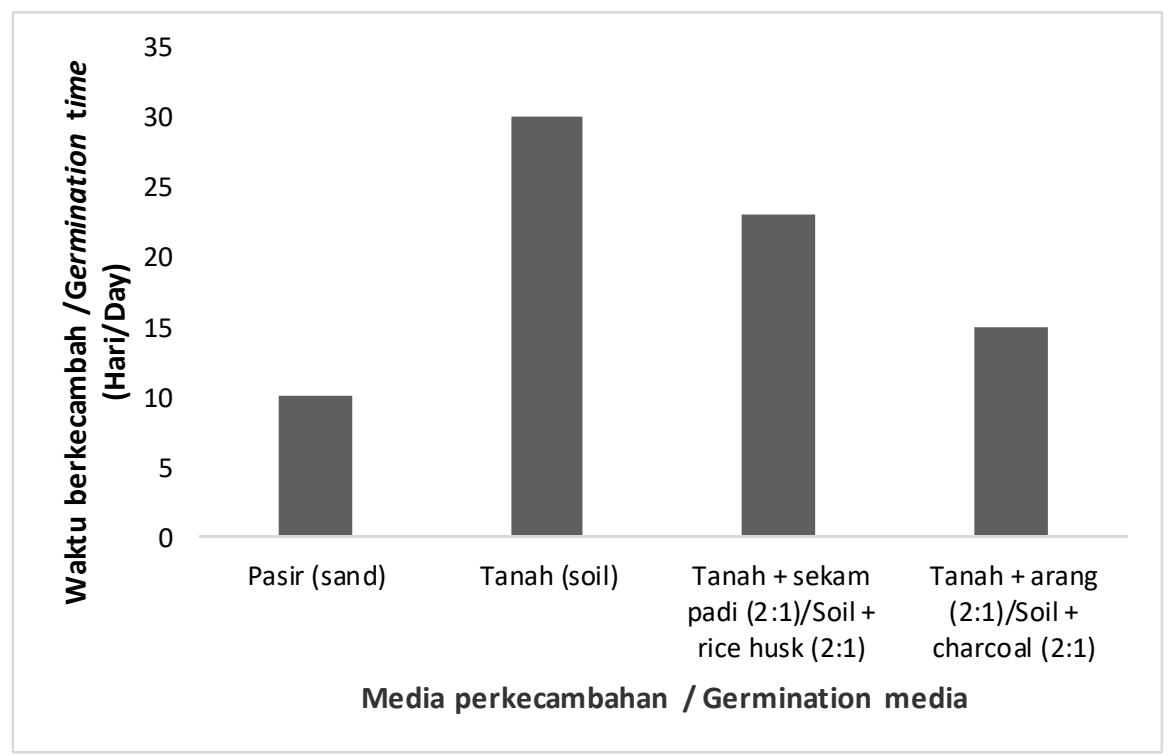

Gambar (Figure) 3. Waktu berkecambah benih kayu gula pada berbagai media (Germinating time of sugarwood seeds on various media)

\section{Nilai kecambah}

Berdasarkan hasil analisis sidik ragam pada Tabel 1, berbagai perlakuan media berbeda nyata terhadap parameter nilai kecambah benih kayu gula (A. polystachya). Perlakuan media pasir memiliki persentase 
nilai kecambah 13,80\%. Perlakuan media tanah + sekam padi memiliki persentase nilai kecambah 11,65\%. Perlakuan media tanah + arang memiliki persentase nilai kecambah yaitu $10,32 \%$, sedangkan perlakuan media tanah memiliki nilai kecambah 7,52\%.

\section{B. Pembahasan}

Proses perkecambahan benih merupakan suatu rangkaian komplek dari perubahan morfologi, fisiologi, dan biokimia tanaman (Sutopo, 1993). Proses pertumbuhan kecambah sangat dipengaruhi oleh faktor internal tanaman dan faktor lingkungan. Media tanam merupakan salah satu faktor yang berpengaruh terhadap perkecambahan benih. Media perkecambahan yang akan memberikan hasil terbaik adalah media perkecambahan yang optimum, yaitu media yang mampu menyediakan semua unsur hara dan air yang dibutuhkan oleh tanaman, sehingga mampu meningkatkan pertumbuhan tanaman itu sendiri (Taryana, 2019).

Apabila dilihat berdasarkan parameter daya tumbuh benih kayu gula, penggunaan berbagai media tidak berpengaruh nyata terhadap daya tumbuh benih kayu gula (Tabel 1). Dapat dikatakan bahwa perlakuan media tidak mempengaruhi pertumbuhan benih kayu gula. Namun daya tumbuh tertinggi dicapai pada media campuran tanah dan sekam padi $(91,33 \%)$ dan daya tumbuh terendah pada media tanah $(64,67 \%)$. Selain itu daya tumbuh yang tinggi pada benih kayu gula dikarenakan benih kayu gula termasuk ke dalam jenis intermediate, hal ini berdasarkan hasil pengukuran kadar air benih sebelum disemaikan yaitu berkisar antara 11,22\% 13,89\%. Nurhasybi (2017) mengemukakan bahwa benih intermediet memiliki kadar air antara 12\%-30\%. Benih intermediet memiliki daya tumbuh yang tinggi apabila langsung di semaikan yaitu 60\%-90\% (Nurhasybi, 2017).

Pada penelitian ini, benih kayu gula mulai berkecambah pada 10 hari setelah tanam di media pasir. Media pasir memiliki porositas yang tinggi sehingga akar mudah menembus media tersebut. Perkecambahan kayu gula $(A$. polystachya) menggunakan media pasir memiliki waktu berkecambah lebih cepat bila dibandingkan dengan hasil penelitian Rai (2014) dengan media tanah dan kompos (3:1), benih kayu gula (A. polystachya) mulai berkecambah pada 21 hari setelah tanam. Penggunaan media berpengaruh secara nyata terhadap kecepatan berkecambah benih kayu gula. Penggunaan media pasir menghasilkan kecepatan berkecambah tercepat dengan nilai $14,00 \%$ per etmal. Penggunaan media tanah menghasilkan kecepatan berkecambah terlambat dengan nilai 32,33\% per etmal. Benih kayu gula pada media tanah mulai berkecambah pada waktu 30 hari setelah tanam. 


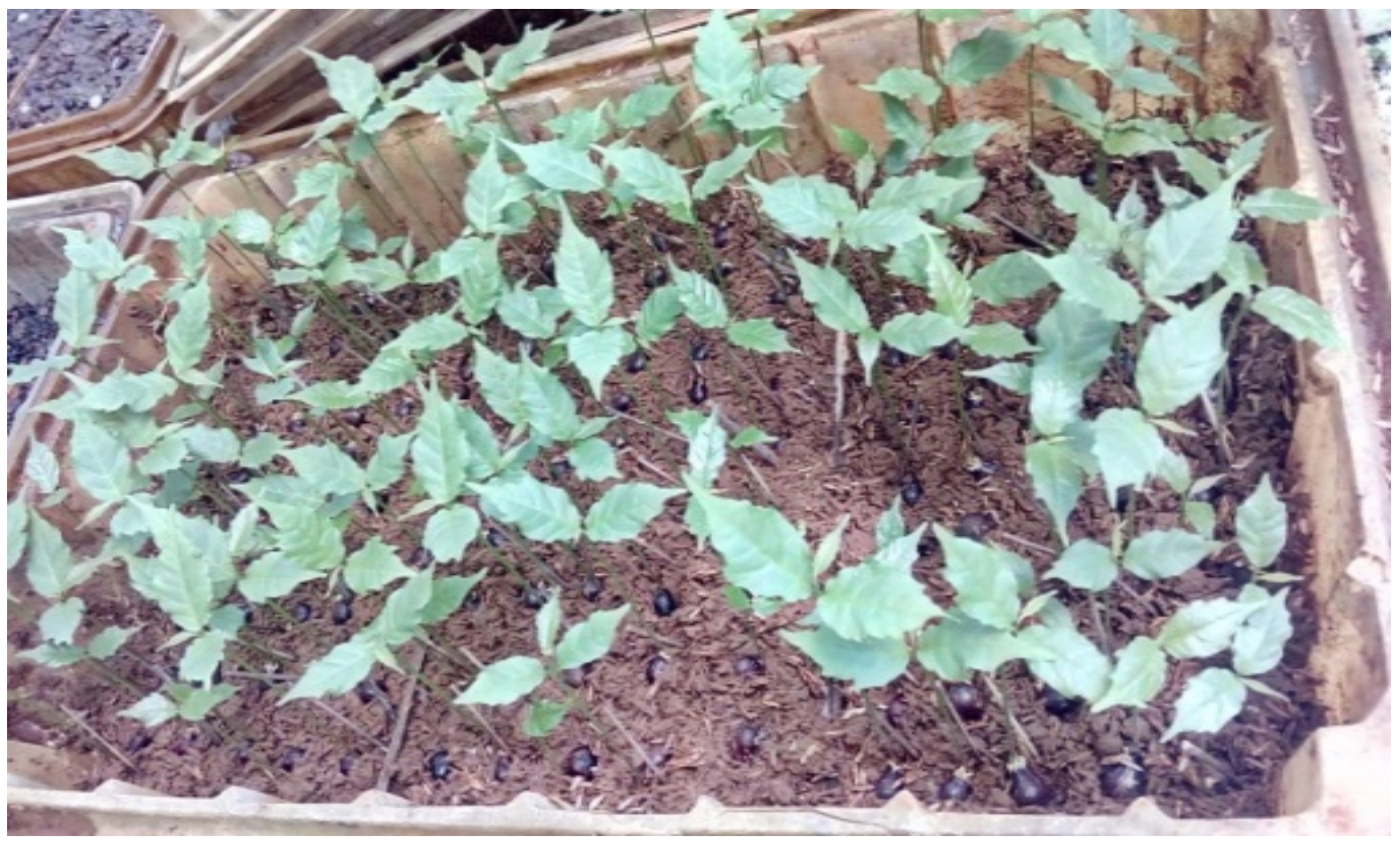

Gambar (Figure) 6. Aphanamixis polystachya 30 hari setelah tanam (Aphanamixis polystachya 30 days after planting)

Berdasarkan hasil analisis sidik ragam berbagai perlakuan media berpengaruh nyata terhadap parameter nilai kecambah benih kayu gula. Perlakuan media pasir memiliki nilai kecambah tertinggi yaitu $13,80 \%$. Sedangkan nilai kecambah terendah adalah pada media tanah 7,52\%. Benih dengan nilai kecambah tinggi juga akan mampu tumbuh menjadi bibit dengan optimal (Tambunsaribu et al., 2017).

Media perkecambahan merupakan salah satu faktor yang mempengaruhi perkecambahan benih (Akbar, 1992; Lakitan, 2004). Media yang digunakan untuk perbanyakan tanaman mempunyai beberapa persyaratan, yaitu: cukup kompak (firm and dense) agar kuat menopang tegaknya batang, mempunyai kapasitas pegang air (water holding capacity) yang cukup baik untuk perkembangannya (Hartmann et al.,1990), dan tidak terlalu lembab karena akan merangsang pertumbuhan jamur yang dapat menyebabkan penyakit (Saridan \& Noor, 2013).

\section{KESIMPULAN}

Penggunaan berbagai media (pasir, tanah, tanah + sekam padi, tanah + arang) berpengaruh nyata terhadap kecepatan berkecambah dan nilai kecambah benih kayu gula (A. polystachya). Penggunaan media pasir 
memiliki saat berkecambah benih kayu gula (A. polystachya) tercepat yaitu 10 hari setelah tanam. Penggunaan media pasir memiliki kecepatan berkecambah terbesar yaitu 14,00\% per etmal sedangkan media tanah memiliki kecepatan berkecambah terlambat yaitu 32,33 $\%$ per etmal. Nilai kecambah benih kayu gula tertinggi adalah pada penggunaan media pasir $(13,80 \%)$ sedangkan nilai kecambah terendah pada penggunaan media tanah (7,52\%). Penggunaan berbagai media (pasir, tanah, tanah + sekam padi, tanah + arang) tidak berpengaruh nyata terhadap daya tumbuh dan kadar air benih kayu gula, namun campuran media tanah dan sekam padi memperlihatkan daya tumbuh tertinggi $(91,33 \%)$

\section{UCAPAN TERIMA KASIH}

Penulis mengucapkan terima kasih kepada $\mathrm{Bu}$ Lincah Andadari atas bantuan pengolahan data, Rahmawati dan Wahyu yang telah membantu penelitian di persemaian Silvikultur, Pusat Standardisasi Instrumen Pengelolaan Hutan Berkelanjutan.

\section{DAFTAR PUSTAKA}

Akbar, A. (1992). Aspek-aspek penting uji perkecambahan benih pohon menurut ACFTSC. Jurnal Penelitian dan Pengembangan Kehutanan, 8 (2), 5-10.

Anggraeni, M., Prayitno, G., Hariyani, S., \& Wahyuningtyas, A. (2013). Bio-pore as an alternative eco drainage technology to control flooding in Malang City (Case study: Metro Sub-Watershed). 3(2), 23-28.
Djavanshir, K., \& Poerbeik, H. (1976). Germination value: A new formula. Silvae Genetica, 25, 79-83.

Hartmann, H.T., Kester, D.E., Davies, F. T. (1990). Plant Propagation Principles and Practices. Prentice-Hall International, Inc.

Jumini. (2006). Viabilitas benih sebagai indikator tingkat pencemaran lingkungan. Jurnal Floratek, 2, 12-18. http://jurnal.unsyiah.ac.id/floratek/article/vie $\mathrm{w} / 69 / 64$

Kamil. (1982). Teknologi Benih. Angkasa Bandung.

Lakitan, B. (2004). Dasar-dasar Fisiologi Tumbuhan. PT Raja Grafindo Persada.

Mathew, A., Shakheel, M., \& Hedge, B. K. (2017). Therapeutic uses of Aphanamixis polystachya: A Review. International Journal of Pharma and Chemical Research, 3(2), 144-148.

Nurhasybi. (2017). Pengujian mutu benih jenisjenis rekalsitran dan intermediet. In I. Siregar \& N. Mindawati (Eds.), Bunga Rampai Karakteristik dan Prinsip Penanganan Benih Tanaman Hutan Berwatak Intermediet dan Rekalsitran (p. 266). IPB Press.

Rai, Y. (2014). Growth and development of medicinal endangered tree species Aphanamixis polystachya (Wall.) Parker in District Meerut, (U.P.) India. International Journal of Multidisciplinary and Current Research, 2011-2014. http://ijmcr.com

Saklani, T., Mishra, A., Sati, B., \& Sati, H. (2012). Pharmacognostic, phytochemical and antimicrobial screening of Aphanamixis polystachya an dangered medicinal. International Journal of Pharmacy and Pharmaceutical Sciences, 4(3), 975-1491.

Saridan, A., \& Noor, M. (2013). Asosiasi dan sebaran jenis pohon penghasil minyak keruing Di PT. Hutan Sanggam Labanan Lestari, Kalimantan Timur. Jurnal Penelitian Dipterokarpa, 7(2), 85-92. https://doi.org/10.20886/jped.2013.7.2.85-92

Soerianegara. (1998). Ekologi Hutan Indonesia. Laboratorium Ekologi Hutan, Fakultas Kehutanan IPB. 
Subarna, T. (2011). Study on influenced of community to cultivate land of protected forest: Case studies in Garut Regency of West Java. Jurnal Penelitian Sosial dan Ekonomi Kehutanan, 8(4), 265-275.

Sudrajat, D. J. (2017). Klasifikasi dan karakteristik benih rekalsitran dan intermediet. In I. Z. Siregar \& N. Mindawati (Eds.), Bunga Rampai Karakteristik dan Prinsip Penanganan Benih Tanaman Hutan Berwatak Intermediet dan Rekalsitran (Edisi I, pp. 5-27). IPB Press.

Suita, E., \& Syamsuwida, D. (2016). Pengaruh pengeringan terhadap viabilitas benih malapari (Pongamia pinnata Merril). Jurnal Perbenihan Tanaman Hutan, 4(1), 9-16. https://doi.org/10.20886

Suryanto, H. (2013). Pengaruh beberapa perlakuan penyimpanan terhadap perkecambahan benih suren (Toona sureni) (Effects of storage of suren (Toona sureni) seeds on germination). Jurnal Penelitian Kehutanan Wallacea, 2(1), 26-40.

http://jurnal.balithutmakassar.org/index.php/ wallacea/article/view/17

Sutopo, L. (1988). Teknologi Benih (Cetakan ke). CV. Rajawali.

Sutopo, L. (1993). Teknologi Benih. Rajawali Press.

Tambunsaribu, D. W., Anwar, S., \& Lukiwati, D. R. (2017). Viabilitas benih dan pertumbuhan bibit kakao (Theobroma cacao L) pada beberapa jenis media simpan dan tingkat kelembaban. Journal of Agro Complex, 1(3), 135. https://doi.org/10.14710/joac.1.3.135142

Taryana, Y. (2019). Pengaruh media tanam terhadap perkecambahan benih kopi arabika ( Coffea arabica L ). Jurnal Agrosains Dan Teknologi, 4(2), 0-5. 